\title{
CLINICAL PHARMACY IN BRAZIL: A BIBLIOMETRIC ANALYSIS
}

\author{
Gustavo da Silva Flexa1, ${ }^{\text {, }}$ Kalilly Fabiane da Silva Grigório², Yasmim Portela Machado de Aguiar ${ }^{3}$, Gabriel \\ da Conceição Rodrigues ${ }^{4}$, Luana de Nazaré Amorim Flexa ${ }^{4}$, Cássia Caroline Dantas de Sousa4, Ana Paula \\ Justino de Faria ${ }^{5}$, Israel Nunes Henrique ${ }^{1}$ and Juarez De Souza ${ }^{3}$
}

1Federal Universityof Western Pará, R. Vera Paz - Salé, Santarém, 68040-255, PA, Brazil; 2Escola Superior da Amazônia, R. Municipalidade, 546 - Reduto, Belém, 66053-180, PA, Brazil; 3State Universityof Pará, Av. Plácido de Castro, 1399 - Aparecida neighborhood, Santarém, 68040-090, Pa, Brazil; ${ }^{4}$ Higher Education Hope Institute, RuaCoaracy Nunes, 3315 - Caranazal, Santarém, 68040-100, PA, Brazil; 5Federal University of Pará, R. Augusto Correa - Guamá, Belém, 66075-110, PA, Brazil

\section{ARTICLE INFO}

\section{Article History:}

Received $14^{\text {th }}$ January, 2021

Received in revised form

$08^{\text {th }}$ February, 2021

Accepted $18^{\text {th }}$ March, 2021

Published online $13^{\text {th }}$ April, 2021

\section{Key Words:}

Clinical Pharmacist;

Scientometrics; Brazil.

*Corresponding author: Gustavo da Silva Flexa

\begin{abstract}
Clinical pharmacy is one of the areas in which pharmacists work that appeared decades ago; however, it is necessary to know the Brazilian reality of scientific production about it. In this context, the objective of this study was to characterize the development of scientific knowledge of clinical pharmacy in Brazil. To answer the general objective of this study, the following questions were used: (I) Which are the main authors who published in the period? (II) What are the temporal trends of the publications? (III) Which were the main journals that published?; (IV) What was the language of the articles?; (V) Which were the main thematic areas found in the publications? The methodology used was a scientometric analysis in two databases. The data obtained were tabulated and transformed into graphs and tables using the Microsoft Excel 2019 program. The results showed that the authors who published the most are linked to the incentive programs of Capes, as well as, the tendency of increase of publications is from 2013 with the approval of the RDC's 585 and 586 of CFF and the law 13021/2014. The journal Einstein São Paulo obtained the highest number of publications, while English was the language of prevalence in the articles, finally, the thematic area of pharmacology and pharmacotherapy was the most studied by them. It is concluded that clinical pharmacy has been growing over the years in Brazil, and this study can support actions that encourage the advancement of studies on the subject in question in the country.
\end{abstract}

Copyright (C) 2021, Renan Gustavo Pacheco Soares et al. This is an open access article distributed under the Creative Commons Attribution License, which permits unrestricted use, distribution, and reproduction in any medium, provided the original work is properly cited.

Citation: Gustavo da Silva Flexa, Kalilly Fabiane da Silva Grigório, Yasmim Portela Machado de Aguiar, Gabriel da Conceição Rodrigues, Luana de Nazaré Amorim Flexa, Cássiacaroline Dantas de Sousa, Ana Paula Justino de Faria, Israel Nunes Henrique and Juarez Desouza. 2021. "Clinical pharmacy in Brazil: a scientometric analysis", International Journal of Development Research, 11, (04), 46020-46023.

\section{INTRODUÇÃO}

Pharmacy is one of the areas in which pharmacists work, which appeared in Europe due to the expansion of hospitals and then the regulation of hospital pharmaceutical activity, however, it was only put into practice by American pharmacists. With the emergence of new drugs with a therapeutic margin close to toxicity accompanied by unwanted effects, the presence of this professional became increasingly required to better meet the needs of users, and with this, the same start to provide clinical care focused on the integral care of the patient (MARTINBIANCHO, ZUCKERMANN \& DE ALMEIDA, 2013). Unlike what happened in hospitals, pharmacists who worked in pharmacies and drugstores lost their identity and proximity with patients in such a way that pharmaceutical interventions were even banned by the American Pharmacists Association, thus limiting pharmacists to drug sales and tying them to bureaucratic issues of these establishments.
For this reason, clinical pharmacy is still a novelty in Brazil due to the historical context experienced as exposed above (PEREIRA \& FREITAS, 2008; PROVIN, MODESTO \& FERREIRA, 2019; MARTINBIANCHO, ZUCKERMANN \& DE ALMEIDA, 2013; ANGONESI \&SEVALHO, 2010). For De Paula (2019) and Pereira $\&$ Freitas (2008), it is correct to say that the pharmacist is prepared to develop clinical activities since he/she has experience in pharmaceutical care that helps to improve clinical services. However, it is a challenge for the class to change behaviors and give subsidies for this professional to be noticed by the managers of public services, as well as the importance of this professional to improve cost reduction, the efficiency of pharmacotherapy, and thus a better quality of life for the user of health services. Therefore, it is necessary to change the concepts related to pharmaceutical activities, bringing their activities closer to patients to improve their pharmacotherapy, opening horizons, and redirecting strategic management to identify and solve problems, ensuring the success of the actions applied to benefit the patient (CAMPESE et al., 2016; ANGONESI \& 
SEVALHO, 2010). The pharmaceutical profession begins to have new directions with the regulation of activities that can be performed by pharmacists, as is the case of the RDC No. 44/2009 that provides for good pharmaceutical practices, where it also addresses the provision of pharmaceutical services such as injectable applications, health screening activities, etc. In 2013, the Federal Council of Pharmacy approves the RDC's 585 and 586, which regulate the clinical activities of the pharmacist and pharmaceutical prescription, giving even more security and support for the performance of this professional in clinical pharmacy. In 2014, law 13.021 was approved, which provides for the exercise and supervision of pharmaceutical activities, where it ensures that pharmacies are health establishments and makes clear the need and requirement for the presence of a professional pharmacist for the legal operation of the establishment. In Brazil advances have been noted with the activities provided by the pharmaceutical professional in the context of clinical care, especially in hospitals, where it has proven increasingly effective due to the proposed interventions to obtain results not only for patients in improving parameters but also for health services, contributing to cost reduction with the actions of pharmacoeconomic (TIGUMAN \& JUNIOR, 2020). Based on this information, it is necessary to know the Brazilian reality of the specific scientific production ofclinical pharmacy, and this becomes possible through scientometrics. The term appeared in the former Soviet Union and became known in the late 1970s, through a publication in the magazine "Scienciometrics", in Hungary (VANTI, 2002). For Viçosi et al. (2018), "scientometric analysis is used as a tool to evaluate the development of scientific activities ". In this context, the objective of the present study was to characterize the development of scientific knowledge of clinical pharmacy in Brazil. To answer the general objective of this work, the following questions were used: (I) Which are the main authors who published in the period? (II) What are the temporal trends of the publications?; (III) What are the main journals that published?; (IV) What is the language of the articles?; (V) What are the main thematic areas found in the publications?

\section{MATERIALS AND METHODS}

The research was conducted in December 2020, seeking quantitatively the articles published on Clinical Pharmacy in Brazil in all years. It was done in two databases: Web of Science, which has a wide coverage as to the number of published articles, and Scielo (Scientific Electronic Library Online), which deals with publications with a more regional approach. It was standardized the use of the keyword "clinical pharmacy" in the two databases, also searching Portuguese and Spanish. The search was then made in Portuguese and Spanish: ("clinical pharmacy") Refined by: DOCUMENT TYPES: (ARTICLE) AND COUNTRIES/REGIONS: (BRAZIL); Time stipulated: Every year. Access to these databases was through the Portal of Periodicals of the Coordination for the Improvement of Higher Education Personnel-CAPES, also known as cafe access. The analysis of the articles took into account the title, abstract, keywords, and other aspects that helped to answer the objectives proposed in this study. It is important to stress that the database did not include any other type of documents such as abstracts of congresses, conferences, books, book chapters, or any other publication outside the aforementioned databases. After the articles were selected, the following information was recorded: (I) Main authors who published in the period; (II) Temporal trends of the publications; (III) Main journals that published the papers; (IV) Languages of the articles; (V) Number of publications found by thematic area. The data obtained were tabulated and transformed into graphs and tables using the Microsoft Excel 2019 program.

\section{RESULTS}

For the Scielo and Web of Science databases, no articles were found in Portuguese and Spanish according to the selected descriptors. For the Web of Science, 43 articles were found. For the Scielo database, 23 articles were found. In total, between the two databases, 66 articles were selected, however, 13 were being shared in two languages or both databases. For this, they were excluded or considered only once. We then followed with 53 articles found in the two databases.

Table 1. List of authors with the number of publications on Clinical Pharmacy in Brazil

\begin{tabular}{lclc}
\hline Author & $\begin{array}{c}\mathrm{N}^{\circ} \text { of } \\
\text { articles }\end{array}$ & \multicolumn{1}{c}{ Author } & $\begin{array}{c}\mathrm{N}^{\circ} \text { of } \\
\text { articles }\end{array}$ \\
\hline De lyra, dp & 5 & Mazzola, pg & 1 \\
De melo, do & 3 & Mendonca, sdm & 1 \\
Fernandez-llimos, f & 2 & Modesto, acf & 1 \\
Leopoldino, rd & 2 & Moghaddas, a & 1 \\
Aguiar, pm & 1 & Moriel, p & 1 \\
Carlotti, a & 1 & Neri, edr & 1 \\
Carlotto, j & 1 & Nery, m & 1 \\
Cazarim, md & 1 & Pereira, ml & 1 \\
Correr, cj & 1 & Polisel, cg & 1 \\
Da cunha, sfd & 1 & Ramalho-de-oliveira, d & 1 \\
Da rosa, k & 1 & Saraiva, rm & 1 \\
Do nascimento, arf & 1 & Silveira, mpt & 1 \\
Dos santos, ga & 1 & Werner, rpb & 1 \\
Franklin, bd & 1 & bouças, e & 1 \\
Gomes, cm & 1 & Souta, mm & 1 \\
Guaraldo, l & 1 & Okumura, lm & 1 \\
Kauffman, ys & 1 & Visacri, mb & 1 \\
Kaye, ks & 1 & Miranda, tmm & 1 \\
Lima, lf & 1 & Ferracini, ft & 1 \\
Lopes, fm & 1 & Borges filho, wm & 1 \\
Machado, fb & 1 & Galato, d & 1 \\
Marques, lam & 1 & De castro, llc & 1 \\
Martinbiancho, jk & 1 & & \\
\hline
\end{tabular}

Diversity was found in the authorship of the papers, the 53 articles were divided among 45 authors. The most frequent authors in publications on clinical pharmacy in Brazil were: DE LYRA, DP (5 articles), DE MELO (3 articles), FERNANDEZ-LLIMOS, F (2 articles), and LEOPOLDINO, RD (2 articles). The remaining authors had only one publication in the period studied, as shown in Table 1. One justification for the aforementioned authors to delve deeper into the theme may be the fact that three of the four authors who published the most are funded by CAPES/CNPQ, corroborating Wainer and Vieira (2013), who propose that research productivity grants correlate with bibliometric measures.

Time trends of publications: In the last two decades, studies related to clinical pharmacy have increased significantly from the year 2013 (3 articles), with the highest number of publications in the year 2019 (10 articles) (Table 1).

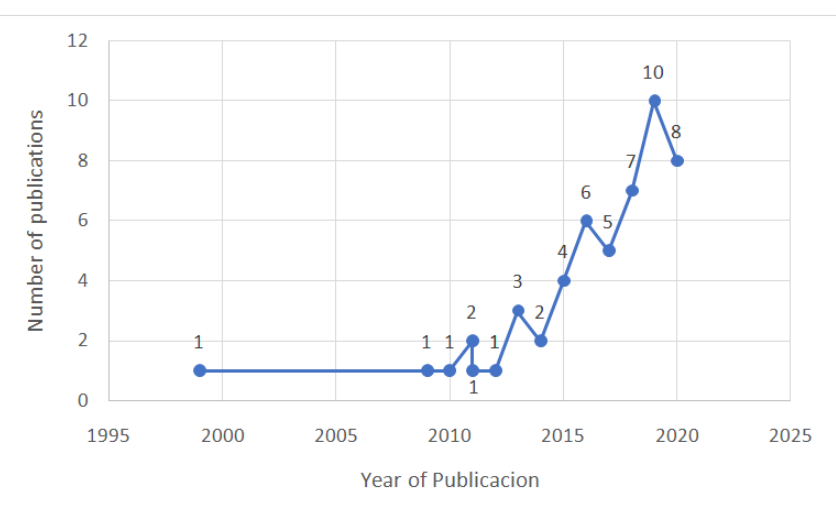

Figure 1. The number of publications related to the Clinical Pharmacy theme

By evaluating the graph it is possible to notice the first publication in 1999, which remains the only research addressing the theme of clinical pharmacy in Brazil for a decade, and only from 2009 other publications start to appear, correlating the publications from then on to what we have as a milestone in the pharmaceutical profession, which is the RDC No. 44/2009 were works in the area start to appear annually, although still in a low number. The increase in the number 
of publications begins to have a slight growth in 2013 with the publication of three articles. This growth can be related to the approval of resolutions 385 and 386 of the Pharmacy Council, where they approve the clinical activities and pharmaceutical prescription in Brazil, opening new horizons and further establishing the clinical activities in which the pharmacist can practice. In 2014, there was a slight decrease in publications, however, from then on, law 13.021 was approved, which provides for the exercise and supervision of pharmaceutical activities, causing professionals to seek to adapt to the requirements and act effectively and supported by law. From 2015 on, there is a tendency of growth, reaching 10 publications in 2019, and we can relate the increase of publications to the CFF resolutions (585 and 586) and the law 13.021 that boosted the advancement of clinical pharmacy in Brazil. Besides the RDC's, the CFF also creates the Support Program for Pharmaceutical Care in Health Care (PROFAR), which aims to train pharmacists to better develop their clinical activities.

Table 2. Relationship between journals with the number of publications on Clinical Pharmacy in Brazil

\begin{tabular}{lc}
\hline Journal & $\mathrm{N}^{\circ}$ of \\
& Articles \\
\hline Einstein São Paulo & 6 \\
International Journal of Clinical Pharmacy & 4 \\
Brazilian Journal of Pharmaceutical Sciences & 4 \\
Collective Health Science & 3 \\
Bmc Health Services Research & 2 \\
Clinics & 2 \\
Journal of Evaluation in Clinical Practice & 2 \\
Journal of Oncology Pharmacy Practice & 2 \\
Latin American Journal of Pharmacy & 2 \\
Plosone & 2 \\
Research in Social Administrative Pharmacy & 2 \\
Paulista JournalofPediatrics & 2 \\
American Journal of Pharmaceutical Education & 1 \\
AnnalsofPharmacotherapy & 1 \\
BmcPediatrics & 1 \\
Bmj open & 1 \\
British Journal of Clinical Pharmacology & 1 \\
Currents in Pharmacy Teaching and Learning & 1 \\
UNIFAP ScientificStation & 1 \\
Journal of Clinical Pharmacy and Therapeutics & 1 \\
Journal of Managed Care Pharmacy & 1 \\
Journal of Parenteral and Enteral Nutrition & 1 \\
JournalofPatient Experience & 1 \\
Health World & 1 \\
Pharmacotherapy & 1 \\
Qualitative Health Research & 1 \\
Journal of the Brazilian Society of Tropical Medicine & 1 \\
Journal of Epidemiology and Infection Control & 1 \\
Revista de Saude Publica & 1 \\
Therapeutics and clinical risk management & 1 \\
Physis: journal of public health & \\
Text\&contextnursing & 1 \\
\hline
\end{tabular}

Main Journals that published the papers: Given the results about the main journals described in Table2, high diversity was found in the number of journals that published on the theme, totaling 32 different periodicals. Those with the highest frequency of occurrence were Einstein São Paulo (6 articles), followed by the International Journal of Clinical Pharmacy (4 articles), and the Brazilian Journal of Pharmaceutical Sciences (4 articles), CienciaSaúdeColetiva (3 articles), Bmc Health Services Research (2 articles), Clinics (2 articles), Journal of Evaluation in Clinical Practice (2 articles), Journal of Oncology Pharmacy Practice (2 articles), Latin American Journal of Pharmacy ( 2 articles), Plos one ( 2 articles), Research in Social Administrative Pharmacy (2 articles), and RevistaPaulista de Pediatria ( 2 articles). The remaining journals published only 1 article. The journal Einstein São Paulo was the journal that stood out the most due to the number of publications, which has the intention to divulge and register scientific productions in the health area since 2003. Due to Einstein updates as the realistic simulation in pharmacy, this may corroborate with Tiguman\& Junior (2020), who point out advances in the provision of clinical pharmacy services in the hospital environment in Brazil, which may be related to the magazine being at the top of the publications on this theme. The second journal in some publications was the International Journal of Clinical Pharmacy, which is a specific periodical for publications related to clinical pharmacy and pharmaceutical sciences that have been published since 1965. And the third was the Brazilian Journal of Pharmaceutical Sciences, which aims to disseminate the advances of pharmaceutical sciences in Brazil and worldwide. It can be observed that most of the publications are in specific journals of Pharmaceutical Sciences and Health Sciences.

Publication Languages: By analyzing figure 2 it is possible to observe that the largest number of publications was in English (49 articles), followed by Portuguese (4 articles). The great difference in the number of publications is because the journals standardize English as the official language for submission in the periodicals, as well as, the journals with higher qualis/impact factors are under the organization of other countries and these require that the articles are generally in English. There may also be other publications in grey literature formats in Portuguese or other languages, due to the diversity of the material published in this writing model as described by Botelho and de Oliveira (2017).

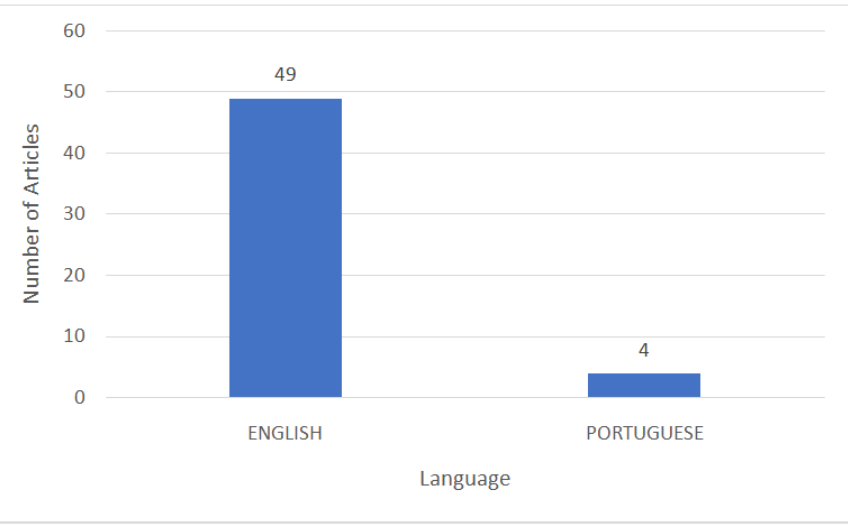

Figure 2. Main languages used in the publications on Clinical Pharmacy in Brazil

For Finardi and Guimarães (2017) the role of foreign languages has a great influence on the internationalization process, mainly due to the low proficiency in English in Brazil, which becomes an obstacle to the development of the internationalization of publications.

Number of publications found by subject area: In Table3, most publications in the period are inserted in the thematic area of pharmacology and pharmacy (20 articles), which was already expected because the theme is an area of pharmacy. The second most studied thematic area was general and internal medicine, which is due to the role of the clinical pharmacist being directly linked to it.

Table 3. Publications by subject area in the period studied

\begin{tabular}{lr}
\hline Thematic area & $\mathrm{N}^{\circ}$ of articles \\
\hline Pharmacology pharmacy & 20 \\
Medicine general internal & 11 \\
Public environmental occupational health & 8 \\
Health care sciences services & 7 \\
Multidisciplinary sciences & 3 \\
Pediatrics & 3 \\
Education scientific disciplines & 2 \\
Medical informatics & 2 \\
Oncology & 2 \\
Infectious diseases & 1 \\
Information science library science & 1 \\
Nutrition dietetics & 1 \\
Parasitology & 1 \\
Social sciences biomedical & 1 \\
Social sciences interdisciplinary & 1 \\
Tropical medicine & 1 \\
Nursing & 1 \\
\hline
\end{tabular}


It is possible to observe that the clinical pharmacist is a professional who acts effectively in several areas as shown in table3, which cites 17 thematic areas in which clinical pharmacists are inserted in the performance of their activities. This fact corroborates Provin et al. (2019), where it states that "clinical pharmaceutical activities can be developed through numerous clinical services. These services are expressed in the most diverse areas.

\section{CONCLUSIONS}

The present work showed the proportion that Clinical Pharmacy has been gaining in Brazil in the last 20 years, increasing from only one publication in 1999 to 10 publications in 2019 and with these results on the knowledge of the Brazilian reality of specific scientific production of clinical pharmacy it is possible to subsidize actions aimed at the incentive by the competent bodies to continue the advances of scientific research in clinical pharmacy in Brazil. It is important to emphasize the growth of publications from the regulation of the clinical activities of the pharmacist exposed in the RDC's 585 and 583 of 2013 of the Federal Pharmacy Council and Law 13021 that seem to have driven this increase, as well as, pushed the pharmacist class to develop their clinical attributions to improve the provision of services to patients. In this way, this study has important relevance to provide a basis for the research, greatly, using the necessary resources and tools that deal with this theme that is on the rise in Brazil and still needs complementary studies, to evaluate if Brazil has followed the other countries regarding the theme in question.

\section{REFERENCES}

Resolution of the Collegiate Board of Directors - RDC n. 44, of August 17, 2009. Dispõe sobre Boas Práticas Farmacêuticas para o controle sanitário do funcionamento, da dispensação e da comercialização de produtos e da prestação de serviços farmacêuticos em farmácias e drogarias e dá outras providências. Diário Oficial da União, Brasília, DF, 18 Aug. 2009. Section 1, p. 78-81.

ANGONESI, Daniela; SEVALHO, Gil. Pharmaceutical care: conceptual and critical foundation for a Brazilian model. Ciênc. saúde coletiva, Rio de Janeiro, v. 15, suppl. 3, p. 3603-3614, Nov. 2010. Available from $<$ http://www.scielo.br/scielo.php? script $=$ sci_arttext\&pid=S1413-81232010000900035\&lng=en\& nrm $=$ iso $>$. access on 18 Dec. 2020. https://doi.org/10.1590/ S1413-81232010000900035.

BOTELHO, R. G.; DE OLIVEIRA, C. da C. White andgray literatures: a conceptual review. Ciência da Informação, v. 44, n. 3, 26 Jun. 2017.

BRAZIL, Federal CouncilofPharmacy. Resolution CFF No. 585, of August 29, 2013. Regulamenta as atribuições clínicas do farmacêutico e dá outras providências. Diário Oficial da União, Brasília, DF, 25 Sep. 2013 - Section1, p.186. Availableat: $<$ http://www.cff.org.br/userfiles/file/ resolucoes/585.pdf $>$. Accessed on: 16 Dec. 2020

BRAZIL, Federal Council of Pharmacy. Resolution CFF No. 586, of August 29, 2013. Regula a prescrição farmacêutica e dá outras providências. Diário Oficial da União, Brasília, DF, 26 Sep. 2013 - Section 1, p. 136. Available at: <http://www.cff.org.br/ userfiles/file/ resolucoes/586.pdf> Accessed on: 16 Dec. 2020
BRAZIL, Subchefia para assuntos jurídicos da Casa Civil. Law No. 13.021, of August 8, 2014. Provides for the exercise and supervision of pharmaceutical activities. Diário Oficial da União, Brasília, DF, Aug. 8, 2014c. Section 1, p.1, extra edition. Available at: $<$ http://www. planalto.gov.br/ccivil_03/_Ato20112014/2014/Lei/ L13021.htm>. Accessedon: 10 Dec. 2020.

CAMPESE, Marcelo et al. Atuação clínica do farmacêutico / organização de Luciano Soares...[et al.] - Florianópolis : Ed. da UFSC, 2016.

FEDERAL COUNCIL OF PHARMACY. Program of Support for Pharmaceutical Care in Health Care - PROFAR / Conselho Federal de Farmácia. - Brasília: Federal Pharmacy Council, 2016.

DE PAULA et al., Cristiane Coimbra. Farmácia clínica e atenção farmacêutica [electronicresource] /Organizers Carlos Eduardo PulzAraujo, Iara LúciaTescarollo, Márcia Aparecida Antônio. Ponta Grossa, PR: Atena Editora, 2019.

FINARDI, Kyria Rebeca and GUIMARÃES, Felipe Furtado. Internationalization, rankings, and publications in English the situation in Brazil today. Studies in Educational Evaluation, ISSN-e 1984-932X, ISSN 0103-6831, Vol. 28, No. 68, 2017.

MARTINBIANCHO, Jacqueline Korut; ZUCKERMANN, Joice; DE ALMEIDA, Silvana Maria. Medicamentos na pratica da farmácia clínica [electronicresource]/ Organizers Luciana dos Santos, MaydeSeadiTorriani, Elvino Barros. -Electronic data-. Porto Alegre: Artmed, 2013.

PEREIRA, Leonardo Régis Leira; FREITAS, Osvaldo de. The evolution of Pharmaceutical Care and the perspective for Brazil. Rev. Bras. Cienc. Farm., São Paulo , v. 44, n. 4, p. 601-612, Dec. 2008. Available from $<$ http://www.scielo.br/scielo.php? script $=$ sci_arttext\&pid $=$ S1516-93322008000400006\&lng=en $\&$ nrm $=$ iso $>$. access on 18 Dec. 2020. https://doi.org/10.1590/ S1516-9332200800040000.

PROVIN, Mércia Pandolfo; MODESTO, Ana Carolina Figueiredo and FERREIRA, Tatyana Xavier Almeida Matteucci. Clinicalpharmacy in healthcare: techniquesandclinicalmethods/ Ana Carolina Figueiredo Modesto, Mércia PandolfoProvin, Tatyana Xavier Almeida MatteucciFerreira.-São Paulo, SP: Farmacêutica, 2019.

TIGUMAN, GB; JUNIOR, RM. Economic impact of pharmaceutical interventions on healthcare services from Brazil: a systematic review. Ver Bras Farm Hosp Serv Saude. RevBrasFarmHospServSaude. 2020;11(4):0512. DOI: 10.30968/rbfhss.2020.114.0512.

VANTI, N.A.P. Da bibliometria à webometria: uma exploração conceptual dos mecanismos utilizados para medir o registro da informação e a difusão do conhecimento, Ciência Inf. Brasília, 31: 152-162 (2002).

VIÇOSI, Karen Andreon et al. CIENCIOMETRY: QUALITATIVE AND QUANTITATIVE ANALYSIS OF THE GLOBAL SCIENTIFIC LITERATURE ON ABIOTIC STRESSES IN Jatropha curcas L. Revista Agri-Environmental Sciences, Palmas-TO, v. 4, n. 2, 2018. https://revista.unitins.br/index.php/ agri-environmental-sciences/index

WAINER, Jacques; VIEIRA, Paula. Evaluation of CNPq research productivity grants and bibliometric measures: correlations for all major areas. Perspect. ciênc. inf., Belo Horizonte, v. 18, n. 2, p. 60-78, June 2013. Available from <http://www.scielo.br/ scielo.php?script $=$ sci arttext \&pid $=$ S1413-99362013000200005 $\& \operatorname{lng}=$ en $\&$ nrm $=$ iso $>$. $\quad$ access $\quad$ on 20 Dec. 2020. https://doi.org/10.1590/S1413-99362013 000200005. 